\title{
Glycosylation and sulphation of colonic mucus glycoproteins in patients with ulcerative colitis and in healthy subjects
}

\author{
H Morita, M G W Kettlewell, D P Jewell, P W Kent
}

\begin{abstract}
Studies have been made of mucus glycoprotein biosynthesis in different regions of the lower gastrointestinal tract in normal patients and those with ulcerative colitis (UC), active or inactive, by means of ${ }^{3} \mathrm{H}$-glucosamine $\left({ }^{3} \mathrm{H}\right.$ $\mathrm{GlcNH}_{2}$ ) - ${ }^{35}$ S-sulphate double labelling of epithelial biopsy specimens under culture conditions. The time based rate of ${ }^{3} \mathrm{H}-\mathrm{GlcNH}_{2}$ labelling of mucus in rectal tissue was similar to that in active or inactive UC whereas the rate of ${ }^{35} \mathrm{SO}_{4}{ }^{2}$ labelling was significantly increased in active disease. The ${ }^{3} \mathrm{H}$ specific activities measuring the amount of isotopic incorporation into surface and tissue mucus glycoproteins were increased in patients with active UC compared with normal or inactive subjects. The ${ }^{35} \mathrm{~S}$ specific activities did not differ significantly between patients with active UC and those in remission. In the rectum, glycosylation of mucus glycoproteins decreases with the increasing age of the patient. Regional differences in ${ }^{3} \mathbf{H}$-labelling of mucus components are reported for ascending colon, transverse colon, sigmoid colon, and rectum. Sulphation $\left({ }^{35} \mathrm{~S}\right.$-labelling) was higher in all parts of the colon in left sided UC. Results point to accelerated glycosylation of core proteins in the active phase of UC.

(Gut 1993; 34: 926-932)
\end{abstract}

Mucus glycoproteins are synthesised by goblet cells of the gastrointestinal tract. They contribute to mucosal integrity ${ }^{1}$ and may serve to regulate the growth of microorganisms at the luminal surface. In the colon, mucosal glycoproteins derived from the goblet cells are more highly sulphated in the distal than in the proximal colon. ${ }^{2}$ These sulphated glycoproteins are composed of O-linked oligosaccharide side chains containing fucose, galactose, $\mathrm{N}$-acetylglucosamine, and sialic acids attached to core protein through threonyl and seryl residues via $\mathrm{N}$-acetylgalactosamine. Differences in the extent of glycosylation and sulphation of these glycoproteins have been found in the colon ${ }^{3}$ although the degree of sulphation is variable and may be dependent on the physiological and pathological conditions prevailing. The biological function of sulphated mucus glycoproteins is not well known although they may have enhanced resistance to enzymic degradation by bacteria. ${ }^{45}$

Degradation of the mucus glycoprotein layer may render the colonic epithelium vulnerable to damage and invasion by bacteria. Thus it has been proposed that ulcerative colitis (UC) might be primarily a disorder involving the mucus glycoprotein layer either because of defective synthesis or due to bacterial degradation. With a variety of techniques, abnormalities of colorectal mucus glycoprotein have been reported in UC and Crohn's disease. ${ }^{-11}$ These abnormalities mostly involved reduction in carbohydrate content and in the size of the oligosaccharide side chains with an increase in the low molecular weight mannose rich glycoprotein. These findings are consistent with modified glycosylation and alterations in goblet cell differentiation as expressed by lectin binding or specific carbohydrate residues of colorectal mucus. ${ }^{6}$ By contrast, increased glucosamine synthetase activity, a rate limiting enzyme in glycoprotein biosynthesis, was found in uninvolved rectal mucosa of patients with UC or Crohn's disease. ${ }^{17}$

This paper describes the quantitative biosynthesis of oligosaccharides and their sulphation throughout the normal colon, and in the colon of patients with UC. Experiments were performed in vitro on cultured biopsy specimens. These involved incubation with dual isotopes and fractionation of the labelled macromolecular products by gel chromatography.

\section{Materials and methods}

\section{PATIENTS}

Rectal biopsies on normal patients and patients with UC

Patients with UC were divided into two groups. The first group $(n=20)$ included those in remission maintained on sulphasalazine, olsalazine, or mesalazine. The second group $(n=15)$ consisted of patients in relapse as shown by inflammation on sigmoidoscopy. Other patients with infectious colitis, collagenous colitis, microscopic colitis, or granulomatous colitis were excluded. As normal controls $(n=31)$, rectal biopsy specimens were taken from patients who were under investigation for colonic symptoms but in whom no abnormality had been found.

\section{Specified regional biopsies from the normal} and UC colon

Studies were carried out on 12 patients who underwent flexible sigmoidoscopy or colonoscopy at the John Radcliffe Hospital, Oxford in the course of investigation for diarrhoea, abdominal pain, or rectal bleeding. No abnormality was seen on colonoscopy. In each case at least four biopsy specimens $(2-3 \mathrm{~mm} \times 3 \mathrm{~mm}$, weight about $2 \mathrm{mg}$ each) were taken from four sites (ascending, transverse, and sigmoid colon, 
and rectum). Seven patients with left sided UC who were in remission were also studied. For each site, one biopsy specimen was retained for histology, one for cell protein assay, and two at least were submitted to isotopic labelling in organ culture.

\section{Ethics}

The studies were approved by the Central Oxfordshire research and ethics committee.

\section{Organ culture}

This was performed by the method of Eastwood and Trier. ${ }^{18}$ Biopsy specimens were weighed, washed with RPMI 1640 medium as rapidly as possible after being taken, and transferred to a stainless steel wire grid in the centre well of a plastic culture dish (Falcon Plastic, $60 \times 15 \mathrm{~mm}$ style with centre well, Beckton Dickinson Laboratories Incorporated, Los Angeles, California, USA) and covered with $1 \mathrm{ml}$ culture medium consisting of RPMI 1640 (Gibco Europe Limited, Uxbridge, Middlesex, UK) containing $25 \mathrm{mM}$ Hepes buffer, fetal calf serum (10\%), glutamine ( $4 \mathrm{mM})$, gentamycin $(40 \mu \mathrm{g} / \mathrm{ml})$, and aminobenzylpenicillin $5000 \mathrm{U} / \mathrm{ml}$ at a final $\mathrm{pH}$ of $7 \cdot 4$.

Incubations were carried out at $37^{\circ} \mathrm{C}$ in a

Figure 1: Elution of
${ }^{35}$ S-labelled soluble glycoprotein (tissue mucin) from Sepharose $C L-4 B$ column (method 1: see materials and methods) continuous line, absorption at $280 \mathrm{~nm}$; dotted line, ${ }^{35} \mathrm{~S}$ counts ( $k d p m / p e r$ fraction); (A) normal subject; $(B)$ patient with active UC
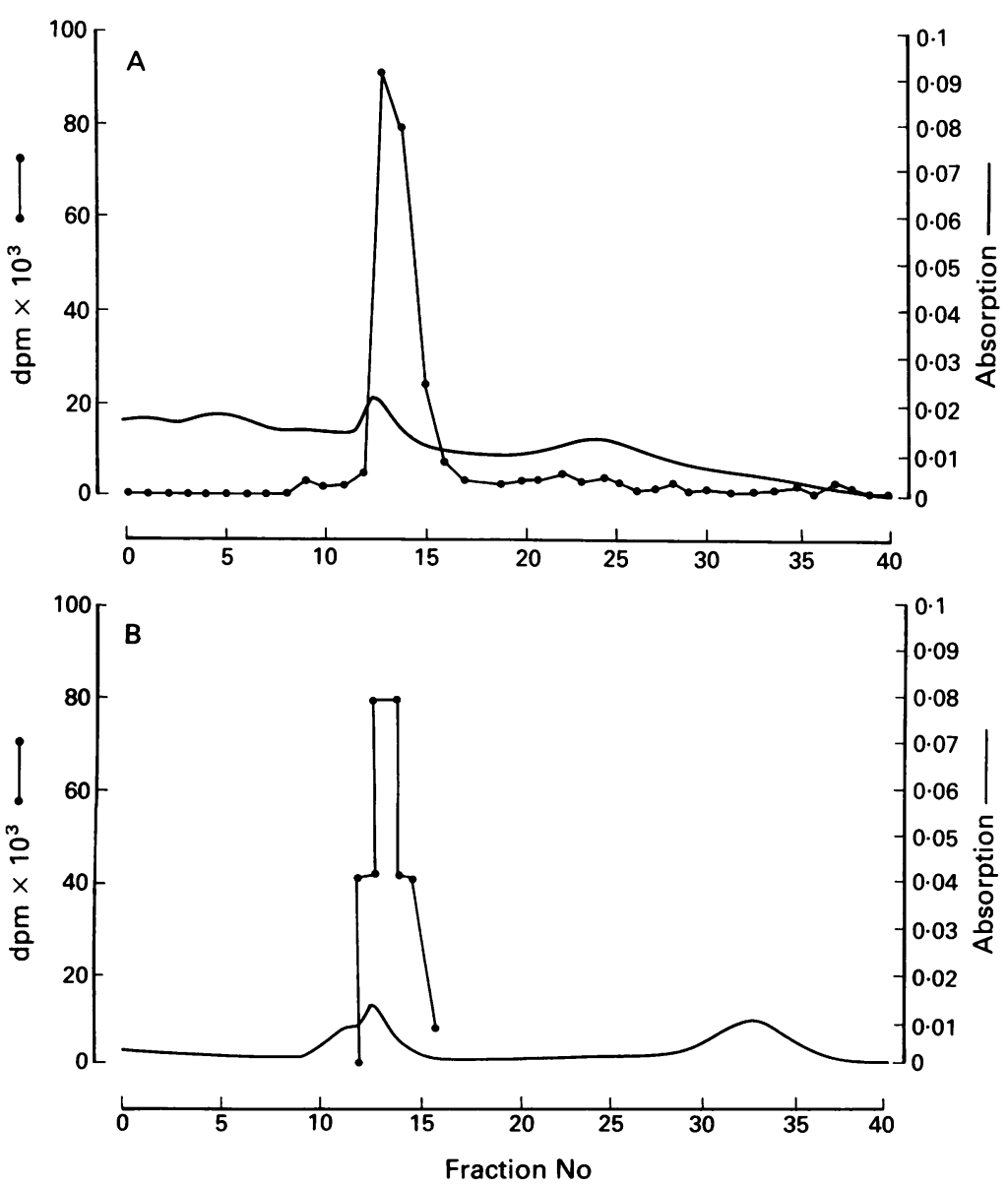

\section{Isotopes and counting procedures}

$\mathrm{Na}_{2}{ }^{35} \mathrm{SO}_{4}(62 \mathrm{mCi} / \mathrm{mmol})$ and $\mathrm{D}-\left[6-{ }^{3} \mathrm{H}\right] \mathrm{glu}-$ cosamine hydrochloride $(27 \mathrm{Ci} / \mathrm{mmol})$ were obtained from Amersham International Plc, England. Taking into account $\mathrm{MgSO}_{4}{ }^{7} \mathrm{H}_{2} \mathrm{O}$ $(100 \mathrm{mg} / \mathrm{l})$ (the only sulphate diluent in RPMI), the final specific activity of ${ }^{35} \mathrm{SO}_{4}{ }^{2-}$ in the culture used throughout was $22 \cdot 1 \mu \mathrm{Ci} \mu \mathrm{mol}$. Metabolic generation of $\mathrm{SO}_{4}^{2-}$ was not considered significant. Similarly competing exogenous glucosamine arising by biosynthesis from glucose in the medium was also insignificant (as shown by Draper and $\mathrm{Kent}^{19}$ for sheep colonic epithelium). The high specific activity of the added tritiated glucosamine ensured adequate labelling of aminosugar constituents (GlcNAc, GalNAc, NANA) as an index of new glycoprotein biosynthesis. The final specific activity of the tritiated glucosamine in the medium cannot be easily ascertained.

Radioactive measurements were made on an LKB 1214 Rackbeta scintillation counter with glass vials and Opti Phase (LKB Products, FSA Laboratory Supplies, UK) or Aquasol II (NEN Research Products Incorporated, Boston, Massachusetts) as scintillants. Standard ${ }^{35} S$-quench data and a ${ }^{3} \mathrm{H} /{ }^{35} S$ dual isotope counting program were introduced manually into the counter from experimentally constructed quenched series based on dioctyl ${ }^{35} \mathrm{~S}$ sulphide as a certified reference standard. A commercial ${ }^{3} \mathrm{H}$-quenched series was obtained from NEN Research Products Incorporated. Experimental vials for assay contained aqueous samples diluted to with water $(1 \mathrm{ml})$ and $9 \mathrm{ml}$ of scintillant.

\section{Protein and glycoprotein assays}

Tissue protein was determined by the method of Lowry et $a l^{20}$ with bovine serum albumin as standard. Glycoprotein content of fractionated samples was estimated either by the Lowry method or spectrophotometrically at $280 \mathrm{~nm}$ with $\alpha_{1}$-seroglycoprotein (orosomucoid) as standard.

\section{Gel chromatography}

Labelled specimens were prepared for chromatographic fractionation by dialysis (cellophane) in the presence of appropriate cold carrier, for 18 hours (twice) at $2^{\circ} \mathrm{C}$ against $0.05 \mathrm{M}$ Tris $\mathrm{HCl}$ buffer (pH 7) containing $0.02 \%$ sodium azide and $0.1 \mathrm{M} \mathrm{NaCl}$. The dialysed solution was concentrated by centrifugation in a Centriprep 10 or 30 apparatus (Amicon Limited, Stonehouse, Gloucester, UK) at $2000 \mathrm{~g}$ for 20 minutes to about 0.5 to $0.8 \mathrm{ml}$.

The labelled concentrate was applied to a gel chromatographic column (Sepharose CL4B, $23.7 \times 2.5 \mathrm{~cm}$ internal diameter, total volume $122 \mathrm{ml})$ prepared in Tris $\mathrm{HCl}$ buffer $(0 \cdot 1 \mathrm{M}, \mathrm{pH}$ $7 \cdot 4)$ containing sodium azide $(0.02 \% \mathrm{w} / \mathrm{v})$ and sodium chloride $(0 \cdot 1 \mathrm{M})$. The void volume was $47 \mathrm{ml}$ and fractionation was carried out by upward elution at a rate of 15 to $20 \mathrm{ml} /$ hour. Fraction volumes were in the range of $3.5 \mathrm{ml}$ to $4 \mathrm{ml}$ Isotopic recovery from the column was greater than $90 \%$ and located in the void volume fraction both with normal and UC material (Figs $1 A$ and $B$ ). 


\section{Histology}

Biopsy specimens before and after culture were monitored by light and electron microscopy. For the latter specimens were fixed with $4 \%$ Karnovsky solution and embedded in epoxy resin.

SEPARATION OF LABELLED GLYCOPROTEINS FROM INCUBATED BIOPSY SPECIMENS

\section{Method 1}

In triplicate experiments for the isolation of mucus, up to eight weighed rectal biopsy specimens from normal subjects or patients with UC were incubated in each culture dish with RPMI medium $(1 \mathrm{ml})$ containing $1 \cdot 25 \mu \mathrm{Ci} \mathrm{D}-\left[6-{ }^{3} \mathrm{H}\right]$ glucosamine and $\mathrm{Na}_{2}{ }^{35} \mathrm{SO}_{4}(9 \mu \mathrm{Ci})$ under the conditions described. The tissue was washed (twice) for 20 minutes with non-radioactive sodium sulphate $(0.08 \mathrm{M}, 1 \mathrm{ml})$. It was then gently agitated on a rotating platform with $2 \mathrm{ml}$ of sodium phosphate buffered saline (PBS) containing $2 \mathrm{mM}$-benzamidine (as a proteinase inhibitor), gentamycin $(40 \mu \mathrm{g} / \mathrm{ml}), \quad$ and aminobenzylpenicillin $(50000 \mathrm{U} / \mathrm{ml})$ for 24 hours at room temperature. After removal of the tissue by low speed centrifugation $(2000 \mathrm{rpm})$, the clear solution, to which cold carriers were added, was twice dialysed (cellophane) against water $(2: 1)$ at $0^{\circ} \mathrm{C}$. The visible clot of mucus (surface mucin containing about $20 \%$ of the total incorporated counts) was removed by centrifugation and the soluble glycoprotein (tissue mucin; $80 \%$ total incorporated counts) in the supernatant was dialysed twice at $0^{\circ} \mathrm{C}$ into $220 \mathrm{ml}$ of Tris HCL buffer $(0.05 \mathrm{M}, \mathrm{pH} 7 \cdot 0)$ containing sodium azide $(0.02 \% \mathrm{w} / \mathrm{v})$ for 18 hours each time. The resulting dialysed solution was con-

Figure 2: Total mucus glycoprotein synthesis and its sulphation during 24 hours of culture, as shown by the incorporation of

${ }^{3} \mathrm{H}$-glucosamine and ${ }^{35} S$-sulphate into rectal biopsy specimens from patients with inactive $(A)$ or active $(B) U C$. Each point is the mean $(S D)$ of four to nine observations. centrated at around $0.5 \mathrm{ml}$ in a Centripep 10 apparatus to remove solutes and components of molecular weight less than 10 kdaltons.

Weighed samples of solutions were taken at each stage for radioactive assay and the concentrated sample fractionated on a Sepharose CL4B column. The fractionation of surface or tissue mucins consistently gave a single ${ }^{3} \mathrm{H}$ and/or ${ }^{35} \mathrm{~S}$ labelled component at the void volume (Fig 1). Radioactivity values reported in the investigation are for the whole of the void volume fraction.

\section{Method 2}

In ${ }^{35} \mathrm{~S} /{ }^{3} \mathrm{H}$ double labelling experiments where the small amounts of tissue available precluded the isolation of labelled mucus fractions, two biopsies were incubated under the foregoing conditions, and washed separately with RPMI medium $(1 \mathrm{ml})$ containing non-radioactive glucosamine $(5 \mathrm{mg})$ and sodium sulphate $(5 \mathrm{mg})$. Surface visible mucus was removed manually from biopsy specimens under an inverted microscope. The carbohydrate rich constituents (for example, oligosaccharides) were separated by aqueous alkaline extraction ( $\mathrm{pH} 12$ by addition of $0.05 \mathrm{M} \mathrm{NaOH}$ ) for 24 hours at room temperature. The resulting solutions, after brief centrifugation to remove debris where required, were acidified ( $\mathrm{pH} 3)$ with acetic acid $(20 \mu \mathrm{l})$. Ethanol $(1 \mathrm{ml})$ was added and the solution was stored for 12 hours at $4^{\circ} \mathrm{C}$. Fractions were thus obtained from surface mucus (surface components) and tissue components (largely although not exclusively of mucus origin). These were pelleted after precipitation by centrifugation (750 $g$ for 10 minutes) and taken up in $1 \mathrm{ml}$ of aqueous alkaline solution ( $\mathrm{pH} 12)$ for counting.

Control experiments with single ${ }^{35}$ S-labelled soluble mucin from method 1 showed that 90 $95 \%$ of the incorporated isotope was recoverable in the carbohydrate rich fractions when submitted to method 2.

\section{STATISTICAL ANALYSIS}

The significance of the differences was assessed by one way analysis of variance and Student's $t$ test.

\section{Results}

\section{HISTOLOGICAL EXAMINATION}

Histological examination of the biopsy specimens cultured for 24 hours showed well preserved goblet cell structure although there was minimal swelling of mitochondria under election microscopy. Goblet cells showed a strong content of acidic mucus as monitored by periodic acid Schiff/alcian blue stain or high iron diamine stain.

RECTAL BIOPSY SPECIMENS: ${ }^{3} \mathrm{H}^{-35}$ S DUAL LABELLING OF TISSUES FROM PATIENTS WITH ACTIVE AND INACTIVE UC

With method 1, preliminary experiments (results not shown) confirmed that pooled rectal biopsy 
Figure 3: Incorporation of ${ }^{35} \mathrm{H}$-glucosamine and ${ }^{35} S$-sulphate into newly formed mucus glycoprotein in rectal biopsy specimens from control subjects. Each point represents the mean $(S D)$ of seven to nine experiments (method 2; see materials and methods).

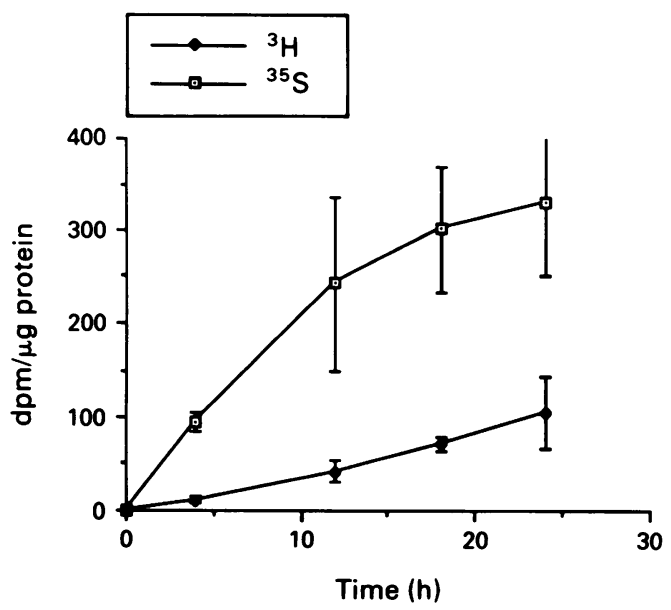

specimens from normal patients rapidly incorporated ${ }^{3} \mathrm{H}$ glucosamine and ${ }^{35} \mathrm{~S}$-sulphate during the first four hours in culture conditions, and at a similar rate during the 20 to 24 hour period after initiation of culture. The time course of ${ }^{3} \mathrm{H}-{ }^{35} \mathrm{~S}$ dual labelling monitored continuously during 24 hours in culture conditions showed progressive labelling of the total isolatable mucin (surface and tissue components, method 1 ). The rate of ${ }^{3} \mathrm{H}$-glucosamine labelling in inactive UC (Fig 2A) was similar to that in active UC (Fig 2B) whereas ${ }^{35} \mathrm{~S}$-labelling rate was distinctively raised in the active condition (Fig 2B). Figure 3 shows the rate of labelling for both isotopes in control tissue.

Table I shows the incorporation of ${ }^{3} \mathrm{H}$ glucosamine and ${ }^{35} \mathrm{~S}$-sulphate (measured as dpm per $\mu \mathrm{g}$ of tissue protein) distributed between surface and tissue mucins (method 1). Glucosamine incorporation both in surface mucins and tissue mucins was significantly higher $(\mathrm{p}<0.001)$ in active UC compared with tissue from patients with inactive UC and normal subjects. Sulphate incorporation, on the other hand, did not differ significantly between patients with active UC and patients in remission (Table I). Similar results were obtained in one experiment where biopsy specimens were taken from inflamed and non-inflamed areas of a colon from a patient with distal UC.

ASSESSMENT OF COLORECTAL MUCUS IN NORMAL SUBJECTS: AGE DEPENDENCE

By the alternative method 2, glycosylation as well as sulphation of newly synthesised mucus by rectal mucosa from normal subjects was found to be slightly increased in women (mean (SD) 115.0 $(43 \cdot 6), 336 \cdot 5(107 \cdot 6), \mathrm{dpm} / \mu \mathrm{g}$ protein) com-

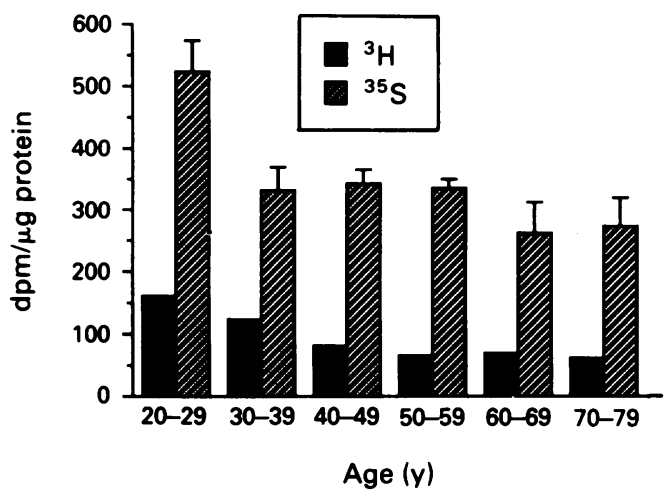

Figure 4: Incorporation of ${ }^{3} \mathrm{H}$-glucosamine and ${ }^{35} \mathrm{~S}$-sulphate into newly formed mucus glycoprotein in rectal biopsy specimens in control subjects of differing ages $(n=5-7$ each age group). Data given as mean (SD) (method 2).

pared with men $(95.0(32.8), 307.6(73.5)$ $\mathrm{dpm} / \mu \mathrm{g}$ protein) but the differences were not significant.

The production of highly glycosylated mucus in the rectum found among normal young patients of either sex gradually decreased with age, accompanied by a fall in the degree of sulphation (Fig 4). No such change with age occurred in other parts of the colon (data not shown).

\section{REGIONAL PATTERN OF LABELLING OF COLONIC} MUCUS: GLYCOSYLATIONANDSULPHATION

Glycosylation and sulphation of colorectal mucin was characterised according to anatomical distribution in mucosal biopsies from normal subjects and patients with left sided UC in remission (Figs 5,6 , and 7 ).

\section{Glycosylation}

${ }^{3} \mathrm{H}$-Glucosamine incorporation into total glycoprotein of normal ascending colon was 122.9 $(33 \cdot 1) \mathrm{dpm} / \mu \mathrm{g}$ tissue protein, decreasing to values of $118.2(33.1)$ in the transverse colon, $96 \cdot 5(27 \cdot 3)$ in the sigmoid colon, and $72 \cdot 0(23 \cdot 7)$ in the rectum. The difference between ascending colon and rectum was significant $(\mathrm{p}<0.008)$.

The total incorporation of ${ }^{3} \mathrm{H}$-glucosamine into glycoprotein in the patients with UC was greater than in normal subjects at all sites in the colon (Fig 6) but values for the ascending colon were not significantly different from those in the rectum.

In all sites a similar gradient in specific activ-

TABLE I Specific activities of mucin fractions derived from ${ }^{35} S$ and ${ }^{3} \mathrm{H}$-labelling of rectal biopsy specimens cultured continuously for 24 hours

\begin{tabular}{lclllll}
\hline & $\begin{array}{l}{ }^{3} \mathrm{H} \text {-surface } \\
\text { mucin(1) }\end{array}$ & $\begin{array}{l}{ }^{3} \mathrm{H} \text {-tissue } \\
\text { mucin }(2)\end{array}$ & $\begin{array}{l}{ }^{3} \mathrm{H} \text {-total } \\
\text { (from }(1) \\
\text { and }(2))\end{array}$ & $\begin{array}{l}{ }^{35} S \text {-surface } \\
\text { mucin }(3)\end{array}$ & $\begin{array}{l}{ }^{3} S \text {-tissue } \\
\text { mucin }(4)\end{array}$ & $\begin{array}{l}{ }^{35} S \text {-total } \\
\text { (from }(3) \\
\text { and }(4))\end{array}$ \\
\hline $\begin{array}{c}\text { Control } \\
(\mathrm{n}=31)\end{array}$ & $45 \cdot 6(20 \cdot 3)$ & $54 \cdot 0(19 \cdot 0)$ & $99 \cdot 6(28 \cdot 8)$ & $206 \cdot 7(48 \cdot 0)$ & $101 \cdot 7(28 \cdot 6)$ & $307 \cdot 9(60 \cdot 4)$ \\
$\begin{array}{c}\text { Active UC } \\
(\mathrm{n}=15)\end{array}$ & $134 \cdot 2(44 \cdot 3)^{\star}$ & $86 \cdot 6(34 \cdot 0)^{\star}$ & $217 \cdot 5(43 \cdot 3)^{\star}$ & $216 \cdot 1(56 \cdot 1)$ & $132 \cdot 4(32 \cdot 2)$ & $348 \cdot 5(60 \cdot 6)$ \\
$\begin{array}{c}\text { Inactive UC } \\
(\mathrm{n}=20)\end{array}$ & $40 \cdot 3(12 \cdot 3)$ & $47 \cdot 9(14 \cdot 7)$ & $88 \cdot 2(15 \cdot 7)$ & $216 \cdot 7(60 \cdot 7)$ & $132 \cdot 6(37 \cdot 4)$ & $386 \cdot 7(64 \cdot 4)$ \\
\hline
\end{tabular}

${ }^{\star} \mathrm{p}<0.001$.

Mucins were separated by method 1 as described in materials and methods; values are mean (SD) dpm $/ \mu \mathrm{g}$ tissue protein; $n=$ number of biopsy specimens. 
Figure 5: Glycosylation (A) and sulphation $(B)$ of total mucin (mean $(S D), n=12$ for controls, $n=7$ for UC). $A C=$ ascending colon; $T C=$ transverse colon; $S C=$ sigmoid colon; $R=\operatorname{rectum}($ method 2 ).
Figure 6: Glycosylation ( $A$ and sulphation $(B)$ of surface mucin (mean (SD), $n=12$ for controls, $n=7$ for UC) (method 2).

Abbreviations as for Fig 5.
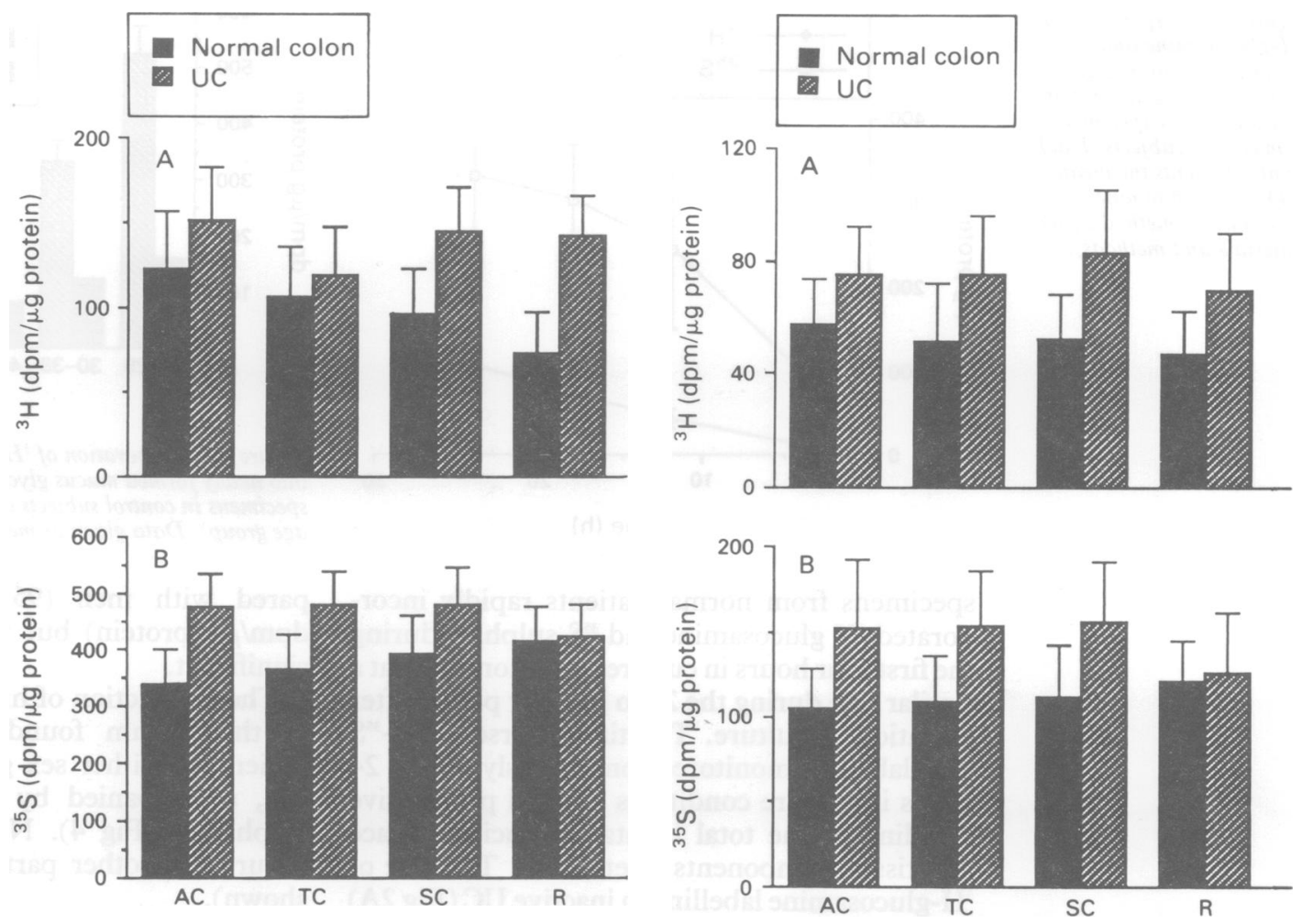

Figure 7: Glycosylation $(A)$ and sulphation $(B)$ of tissue mucin (mean (SD), $n=12$ for controls, $n=7$ for UC) (method 2). Abbreviations as for Fig 5.

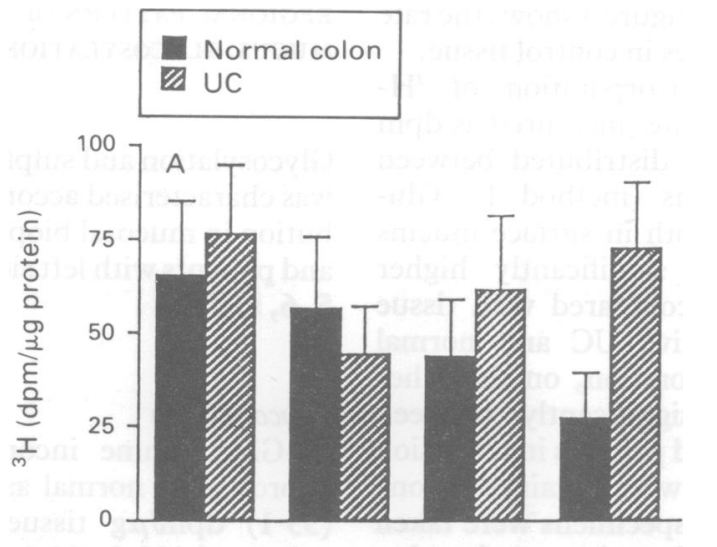

ities of ${ }^{3} \mathrm{H}$-labelled glycoconjugate in the surface mucin fraction was found in normal subjects. Glycosylation in left sided UC in remission was slightly higher than that in normal subjects and was particularly enhanced in the rectum.

In the tissue mucin fraction of normal subjects, the biopsy specimens from the ascending, transverse, and sigmoid colon showed almost the same values for newly synthesised mucus although values were lower in the rectum. In left sided UC in remission, values of glycosylation were similar in all parts of the colon (Fig 7).

Table II summarises the data for the right colon compared with the rectosigmoid.

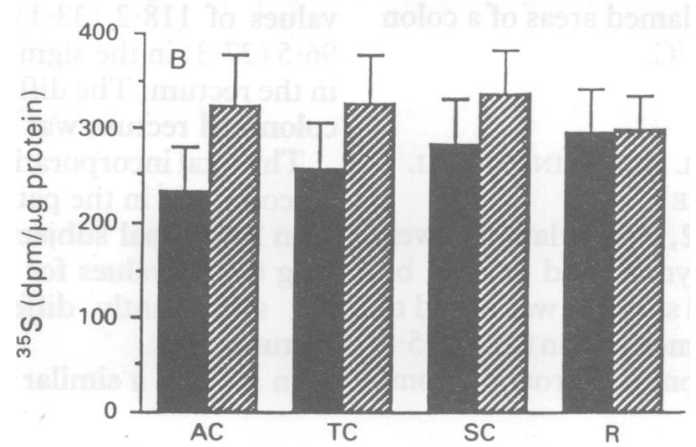

TABLE II Incorporation of ${ }^{3} \mathrm{H}$-glucosamine and ${ }^{35} \mathrm{~S}-\mathrm{Na}_{2} \mathrm{SO}_{4}$ into mucus glycoprotein (surface, tissue, and total) during 24 hours of continuous incubation for the right colon and rectosigmoid in normal controls and in inactive left sided UC (method 2)

\begin{tabular}{|c|c|c|c|c|c|c|c|c|c|}
\hline \multirow[b]{2}{*}{ Region } & \multicolumn{5}{|c|}{ Normal subjects } & \multicolumn{4}{|c|}{ Left side UC } \\
\hline & No & ${ }^{35} \mathrm{H}^{35} \mathrm{~S}$ & $\begin{array}{l}\text { Surface } \\
\text { fraction (1) }\end{array}$ & $\begin{array}{l}\text { Tissue } \\
\text { fraction (2) }\end{array}$ & $\begin{array}{l}\text { Total } \\
\text { (from 1+2) }\end{array}$ & No & $\begin{array}{l}\text { Surface } \\
\text { fraction (3) }\end{array}$ & $\begin{array}{l}\text { Tissue } \\
\text { fraction (4) }\end{array}$ & $\begin{array}{l}\text { Total } \\
\text { (from } 3+4)\end{array}$ \\
\hline $\begin{array}{l}\text { Right hemicolon } \\
\text { Rectosigmoid }\end{array}$ & $\begin{array}{l}48 \\
48 \\
48 \\
48\end{array}$ & $\begin{array}{l}{ }^{3} \mathrm{H} \\
{ }^{35} \mathrm{~S} \\
{ }^{35} \mathrm{H} \\
{ }^{35}\end{array}$ & $\begin{array}{c}60 \cdot 9(19 \cdot 9)^{\star} \\
245 \cdot 5(47 \cdot 4) \\
35 \cdot 2(16 \cdot 2) \\
288 \cdot 4(46 \cdot 8)\end{array}$ & $\begin{array}{r}59.0(18 \cdot 7) \\
115.3(25.5) \\
49.4(16.0) \\
116.1(28.2)\end{array}$ & $\begin{array}{c}119.9(30.9)^{\star} \\
360.8(59 \cdot 7) \\
84.6(27.5) \\
494.5(65.8)\end{array}$ & $\begin{array}{l}25 \\
25 \\
26 \\
26\end{array}$ & $\begin{array}{r}59.6(24.0) \\
323.3(49.9) \\
66.9(19.6) \\
317.0(43.8)\end{array}$ & $\begin{array}{r}75 \cdot 4(18 \cdot 4) \\
148 \cdot 4(33.0) \\
76 \cdot 3(19 \cdot 7) \\
141 \cdot 0(37.9)\end{array}$ & $\begin{array}{l}135.0(34.5) \\
471.7(56.7) \\
142.3(23.6) \\
458.0(70.0)\end{array}$ \\
\hline
\end{tabular}

${ }^{\star} \mathrm{p}<0.008$.

Mucins were separated by method 2 as described in materials and methods; values are mean (SD) dpm/ $\mu \mathrm{g}$ tissue protein; $\mathrm{N}=$ number of biopsy specimens tested. 
Figure 8: Correlation of sulphation $\left({ }^{35} S\right)$ and glycosylation $\left({ }^{3} \mathrm{H}\right)$ in rectum and transverse colon. Labelled glycoproteins isolated by method 2.

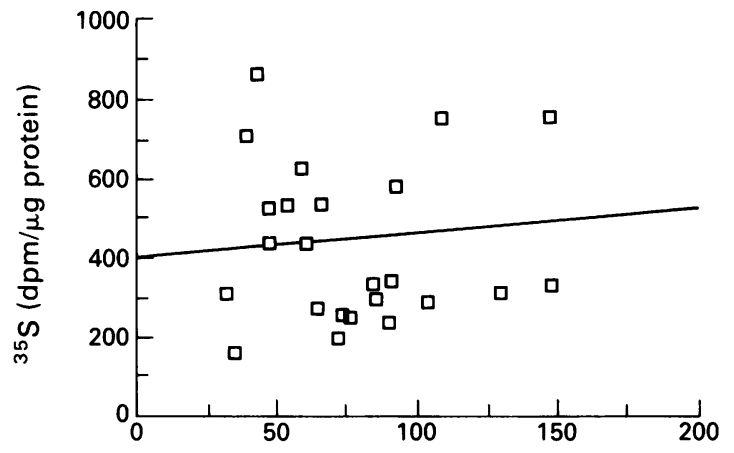

Rectum ${ }^{3} \mathrm{H}$-glucosamine (dpm/ $\mathrm{gg}$ protein)

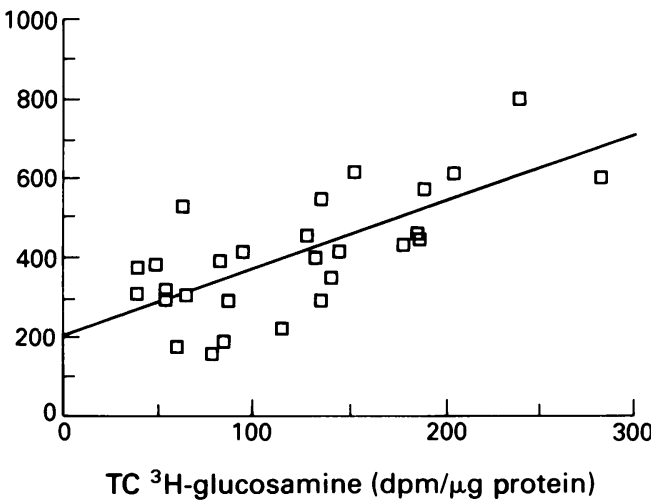

would be secondary to an underlying inflammatory response, whether a defective mucus barrier is involved, or whether they are indicators of abnormal epithelial cell populations. normal subjects.

The surface mucus fraction from the norma subjects showed a similar gradient in sulphation as the total mucus (Table II). Sulphation of surface mucus was higher in all parts of the colon in left sided UC in remission compared with those of normal subjects $(p<0.001)$, although there was no quantitative difference in each region of the colon.

The tissue mucus fraction of normal subjects gave a similar value in each part of the colon. Enhanced sulphation was found in all regions of left sided UC.

There was good correlation between glycosylation and sulphation of glycoprotein in the ascending and transverse colon but no correlation was seen in the rectum (Fig 8).

\section{Discussion}

Formation of epithelial mucus comprises two principal phases; firstly, the synthesis of core protein under genomic control followed by intracellular glycosylation as post-translation processes at the inner and outer membranes of the Golgi apparatus ${ }^{2122}$ and then by sulphation of certain of the assembled oligosaccharide side chains. These post-translational steps are effected by the presence of sugar nucleotide transferases (as in mammalian respiratory epithelium ${ }^{23}$ ), the availability of appropriate acceptors, or by favourable membrane organisation. It follows that post-translational events may be dependent on the physiological conditions in which the relevant enzymes act. The second phase consists in the packaging of the formed glycoprotein and subsequent transport to the exterior by exocytosis, a phase susceptible to neurophysiological, toxicological, and pharmacological regulation.

Biochemical investigation of colonic glycoproteins has pointed to abnormalities in UC. These are believed to include a decrease in the length of oligosaccharide side chains, and coreprotein with a lower than normal content of serine and threonine. Furthermore, mucus secreting cells including goblet cells seem to comprise a heterogenous population in which the final chemistry of the secreted glycoprotein is influenced by the prevailing physiological and pathological conditions. Thus the pathogenesis of UC may well involve changes in composition of mucus and in its physiochemical properties. It is not clear, however, whether such changes

\section{GLYCOPROTEIN LABELLING IN THE RECTAL}

\section{MUCOSA IN ULCERATIVE COLITIS}

In these studies of the rectal mucus, the rate of glycoprotein biosynthesis of mucus glycoproteins has been investigated in patients with active UC and those in remission by ${ }^{3} \mathrm{H}$-glucosamine labelling (as an index of post-translational glycosylation) and ${ }^{35} \mathrm{~S}$-sulphation as an index of The rate of glycosylation in newly synthesised glycoprotein was raised in active UC but returned to values similar to controls when the disease was in remission. The final state of glycoprotein in active UC seems to be poorly sulphated compared with the controls and when the disease goes into remission the extent of sulphation increases beyond control values.

\section{REGIONAL VARIATIONS IN GLYCOPROTEIN \\ LABELLING IN THE COLON}

On the basis of histochemical studies, ${ }^{2}$ it is known that the degree of sulphation of colonic mucus increases throughout the colon and is maximal in the rectum. These studies have quantified both the glycosylation and the sulphation of newly synthesised mucus in different parts of the colon by means of an organ culture technique and labelling with dual isotopes. During the 24 hour culture period, viability of the tissue was shown by a linear rate of ${ }^{3} \mathrm{H}$ glucosamine incorporation and by preservation of cell morphology. In the normal subject, it was shown that the glycoprotein of rectal mucosa tended to be more highly glycosylated and sulphated in women than in men and in both there was a decrease in glycosylation and sulphation with advancing age. No correlation between glycosylation and sulphation was seen in rectal mucus although these two synthetic processes correlated well higher up in the colon. This may reflect at heterogeneity of goblet cells throughout the colon but could also indicate that the regulating mechanisms for glycoprotein synthesis differ in different parts of the colon.

Data obtained from the different anatomical regions of the colon showed that glycosylation was maximal in the ascending colon and decreased progressively towards the rectum. By glycoprotein completion (post-post-translation). 
contrast, sulphation of mucus glycoprotein progressively increased from the right to the left colon, being maximal in the rectum. This confirms previous conclusions based on histochemical analysis. ${ }^{2}$

The studies on patients with left sided UC in remission have shown different patterns to that seen in the normal colon. Both glycosylation and sulphation were greater in the left colon in remission compared with the normal colon suggesting that, even in remission, mucus synthesis is increased. Synthesis also seemed to be greater than normal in the uninvolved right colon and the gradients for glycosylation and sulphation seen in the normal colon were lost.

The significance of these findings in relation to the aetiology and pathogenesis of UC is not clear, but they are consistent with other findings suggesting that the colonic mucus may be abnormal in UC. ${ }^{6-17}$ For example, lectin binding to goblet cells differs in $\mathrm{UC}^{6}$ and the composition of the mucus glycoproteins differs as shown by a decreased content of subspecies IV of the glycoprotein when separated by ion exchange chromatography. ${ }^{916}$

Thus patients with UC may have a basic abnormality in mucus production. Unfortunately it is not possible to be sure whether these changes reflect a primary abnormality, which might render the epithelium more vulnerable to damage, or whether they are secondary effects. Because goblet cells are a heterogenous population $^{16}$ and the epithelial crypt cells of patients are known to be dividing more rapidly than normal even when the UC is in histological remission, ${ }^{24}$ it is conceivable that minor changes in synthesis, composition, and sulphation of mucus might result. Nevertheless, the increase in glycosylation and sulphation in the normal unaffected right colon of patients with left sided disease, especially when they were in good remission, lends support to the hypothesis that the basic defect is within the epithelium. Further studies on regional synthesis of mucus, its regulation, and the composition of the glycoprotein species seems worthwhile in patients with distal disease.

It is envisaged overall that when UC is in its active state, glycosylation of core-protein(s) outstrips subsequent sulphation and results in the formation of less sulphated glycoconjugates. This implied molecular modification is compatible with the histological findings of decreased intracellular sulphated glycoprotein accompanying increased inflammation. ${ }^{16}$ It is also consistent with the view that accelerated exocytosis of such modified or incomplete glycoconjugates may be promoted in pathologically disturbed tissue. Because sulphation is related to resistance to bacterial attack, it follows that in such circumstances the protective mucus barrier would be impaired during active inflammation. There is no evidence in these studies that UC is associated with an underlying primary defect of sulphation of mucus glycoprotein.

The hypothesis that modification of the mucus barrier in active UC is a salient defect in the disease has to be considered in terms of intracellular glycoprotein biosynthesis, mucus exocytosis, and the maintenance of cellular functions in exfoliating circumstances. It seems that in active UC the intracellular biosynthesis is accelerated and exocytosis of sulphated glycoproteins, possibly modified, is enhanced. In remission the results point to exocytosis and biosynthesis becoming more normal but a more highly sulphated glycoprotein is retained intracellularly.

1 Forstner G, Wesley A, Forstner J. Clinical aspects of gastrointestinal mucus. Adv Exp Med Biol 1982: 144: 199-244.

2 Morson BC, Dawson IMP. Gastrointestinal pathology. Oxford: Blackwell Scientific Publications, 1972.

3 Dawson PA, Fillipe MI. Uptake of [35S] sulphate in human colonic mucosa associated with carcinoma: an autoradiographic analysis at the ultrastructural level. Histochem $\mathcal{F}$ 1983; 15: 3-13

4 Rhodes JM, Gallimore R, Elias E, Allan RN, Kennedy JF. Faecal mucus degrading glycosidases in ulcerative colitis and Crohn's disease. Gut 1985; 26: 761-5.

5 Rhodes JM, Gallimore R, Elias E, Kennedy JF. Faecal sulphatase in health and inflammatory bowel disease. Gut 1985; 26: 466-9.

6 Jacobs LR, Huber PW. Regional distribution and alterations of lectin binding to colorectal mucin in mucosal biopsies from controls and subjects with inflammatory bowel disease. from controls and subjects with

7 Teague RH, Fraser G, Clamp JR. Changes in monosaccharide content of mucus glycoproteins in ulcerative colitis. $B M \mathcal{F}$ 1973; $2: 645-6$.

8 Clamp JR, Fraser G, Read AE. Study of the carbohydrate content of mucus glycoproteins from normal and diseased colon. Clin Sci 1981; 61: 229-34.

9 Podolsky DK, Isselbacher KJ. Composition of human colonic mucin: selective alteration in inflammatory bowel disease. $\mathcal{f}$ Clin Invest 1983; 72: 142-53.

10 Culling CF, Reid PF, Dunn WL. A histological comparison of $\mathrm{O}$-acetylated sialic acids of the epithelial mucins in ulcerative colitis, Crohn's disease and normal control. $\mathcal{F}$ Clin Pathol colitis, Crohn's dise

11 Boland CR, Lance P, Levin B, Riddell RH, Kim YS Abnormal goblet cell glycoconjugates in rectal biopsies associated with an increased risk of neoplasia in patients with ulcerative colitis: early results of a prospective study. $G u t$ 1984; 25: 1364-71

12 Boland CR, Clapp NK. Glycoconjugates in the colons of New World monkeys with spontaneous colitis. Association between inflammation and neoplasia. Gastroenterology 1987 92: 625-34.

13 Reid PE, Culling CF, Dunn WL, Ramey CW, Clay MG Chemical and histochemical studies between normal and diseased diseased human gastrointestinal tract. A comparison between normal colon, colonic tumor, ulcerative colitis, and
diverticular disease of the colon. Histochem $\mathcal{f} 1984 ; 16$ : divertic $235-41$.

14 Franzin G, Grigioni WF, Dina R, Scarpa A, Zamboni G. Mucin secretion and morphological changes of the mucosa in non-neoplastic diseases of the colon. Histopathology 1983; 7 707-18.

15 Ehsanullah M, Fillipe MI, Gazzard B. Mucin secretion in inflammatory bowel disease; correlation with disease activity and dysplasia. Gut 1982; 23: 485-9.

16 Podolsky DK, Fournier DA. Alterations in mucosal of colonic glycoconjugates in inflammatory bowel disease defined by

17 Goodman MJ, Kent PW, Truelove S. 1988, 95. 379-87. thetase activity of the colonic mucosa in ulcerative colitis and thetase activity of the colonic mucosa in

18 Eastwood GL, Trier JS. Epithelial renewal in cultured rectal biopsies in ulcerative colitis. Gastroenterology 1973; 64: biopsies

19 Draper P, Kent PW. Biosynthesis of intestinal mucins for utilization of $\left[1{ }^{14} \mathrm{C}\right]$ glucose by the sheep colonic epithelium in vitro. Biochem f 1963; 86: 248-54.

20 Lowry OH, Rosenbrough NJ, Lewis Farr A, Randell RJ Protein measurement with Folin Phenol reagent. $\mathcal{f}$ Bio Chem 1951; 193: 265 .

21 Goochee CF, Gramer MJ, Andersen DC, Barh JB, Rasmussen JR. The Oligosacchardides of glycoproteins: bioprocess factors affecting oligosaccharide structure and their effect on glycoprotein properties. Biotechnology 1991; 9: 1347-54.

22 Rothman JE, Orci L. Molecular dissection of the secretory pathway. Nature 1992; 355: 409-15.

23 Cottrell JM, Hall RL, Sturton RG, Kent PW. Polypeptide $\mathrm{N}$-acetylgalactosaminyl transferase activity in tracheal $\mathrm{N}$-acetylgalactosaminyl transferase activity in tr
epithelial microsomes. Biochem $\mathcal{F}$ 1992; 283: 299-305.

24 Allan A, Bristol JB, Williamson RCN. Crypt cell production rate in ulcerative proctocolitis: differential increments in rate in ulcerative proctocolitis: differential ince
remission and relapse. Gut 1985; 26: 999-1003. 